\title{
Rehabilitasi Prostetik Protesa Jari dengan Bahan Silikon Rtv untuk Mengembalikan Bentuk dan Estetik
}

\author{
A.A.Ayu Agung Subiantari D., Endang Wahyuningtyas, dan Haryo Mustiko D \\ Program Studi Prortodonsia, PPDGS, Fakultas Kedokteran Gigi, Universitas Gadjah Mada \\ JI Denta No 1 Sekip Utara, Yogyakarta, Indonesia; e-mail: subiantari@yahoo.com
}

\begin{abstract}
ABSTRAK
Tangan memiliki fungsi utama untuk menggenggam dan meraba. Organ ini dipergunakan untuk sarana komunikasi penting yang menunjukkan bahasa tubuh dan kontak sosial. Amputasi pada jari atau sebagian jari tangan merupakan kasus yang paling sering dijumpai sebagai bentuk hilangnya sebagian tangan yang dapat menimbulkan dampak buruk secara fisik, psikologis, maupun kerugian secara ekonomi bagi individu. Rehabilitasi prostetik pada amputasi jari menjadi pertimbangan ketika rekonstruksi mikro vaskular merupakan kontraindikasi atau perawatan mengalami kegagalan. Tujuan dari studi kasus ini adalah mengkaji rehabilitasi prostetik protesa jari menggunakan bahan silikon RTV untuk mengembalikan bentuk dan estetik. Pasien telah menyetujui kasusnya dipublikasikan untuk kepentingan ilmu pengetahuan. Pasien laki- laki, 24 tahun datang dengan keluhan kehilangan sebagian jari telunjuk kanan . Riwayat trauma disebabkan oleh tangan kanannya tergilas mesin bubut 6 tahun yang lalu. Tatalaksana kasus : Anamnesa, pemeriksaan klinis, dan rehabilitasi prostetik protesa jari dengan ahan silikon RTV. Protesa jari dengan estetik yang baik dapat memberi dukungan psikologis terhadap pasien.
\end{abstract}

Maj Ked Gi. Juni 2014; 21(1):84-90

Kata Kunci: rehabilitasi , protesa jari, silikon RTV, estetik

ABSTRACT: Rehabilitation Finger Prosthesis with RTV Silicone to Restore Form and Esthetic. The hand has basic functions like grasping and feeling. It is a mean of communication and is of mayor importance for body language and social contact. Finger and partial finger amputations are some of the most frequently encountered forms of partial hand loss causing devastating physical, psychosocial and economic damage to an individual. Prosthetic rehabilitation of amputed finger is considered when micro vascular reconstruction is contraindicated or unsuccessful. The purpose of case study is to review rehabilitation finger prosthesis with RTV silicone to restore form and esthetic. Case : A 24 year old male patient with the complaint of the partially lost right index He had a history of trauma to his right hand on a mechanical lathe 6 years ago: History talking, clinical examination, rehabilitation finger prosthetic with silicon RTV. A well fabricated esthetic prosthesis can help in providing the patient with psycological support.

Maj Ked Gi. Juni 2014; 21(1):84-90

Key words: rehabilitation, prosthetic finger, silicon RTV, esthetic

\section{PENDAHULUAN}

Kebutuhan manusia untuk mengganti bagian tubuh yang hilang kemungkinan telah ada sejak adanya manusia di dunia dengan tujuan untuk mengembalikan penampilan dan fungsi serta membuat individu menjalani hidup secara normal. Cacat ekstra oral yang melibatkan telinga, mata, hidung, serta jari merupakan peristiwa yang sering dijumpai. Amputasi sebagian jari merupakan salah satu kejadian yang paling sering terjadi. Cacat ini dapat disebabkan oleh karena trauma, kongenital dan malformasi, serta penyakit seperti infeksi, diabetes mellitus, ataupun lepra. ${ }^{1-3}$

Amputasi dapat menimbulkan kerugian secara fisik, psikologis dan emosional, stigma sosial, ekonomi serta penampilan (estetik) yang merupakan kejadian yang dapat memicu individu untuk mengalami kesedihan yang berkepanjangan, depresi, kegelisahan (anxiety), kehilangan percaya diri, dan mengisolasi diri dari pergaulan sosial. ${ }^{2-7}$ Apapun yang menjadi penyebab amputasi tersebut luka batin yang ditimbulkanya akan bertahan lama sehingga kondisi ini harus segera diatasi. ${ }^{6}$

Meskipun dengan kemajuan tehnik bedah mikro melalui reimplantasi mikrovaskular telah menyelamatkan banyak kasus amputasi jari, tetapi pada kasus tertentu tindakan bedah kemungkinan mengalami kegagalan dimana protesa pasif dengan estetik yang baik menjadi pilihan perawatan .$^{1-3}$ Protesa berhubungan dengan penggantian 


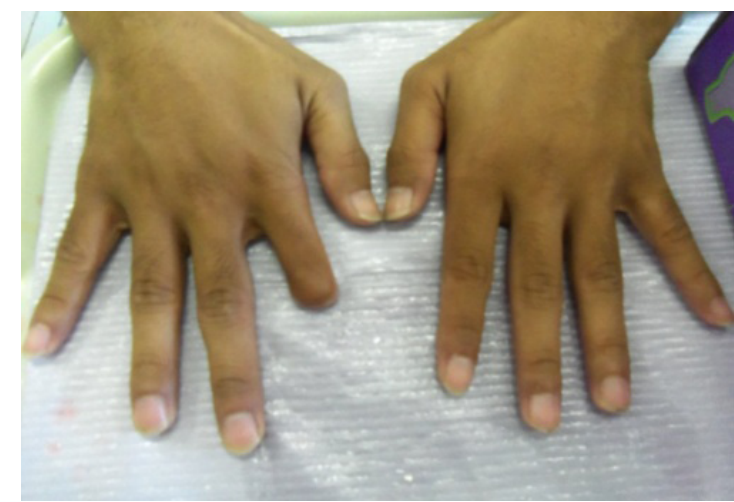

(A)

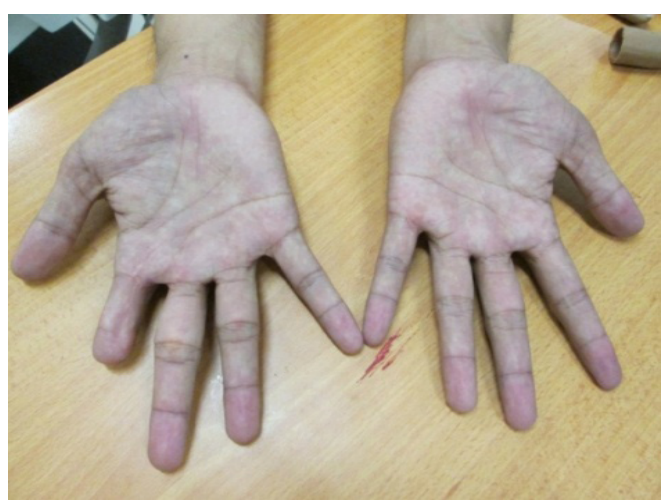

(B)

Gambar 1. Jari pasien sebelum terapi (A). Tampak dorsal tunggul amputasi pada jari telunjuk kanan, (B) Tampak ventral tunggul amputasi pada jari telunjuk kanan

organ tubuh yang hilang menggunakan suatu bahan artificial (Glossary of Prosthodontic Term) . Protesa dapat melindungi tunggul amputasi dari rasa sakit dan hipersensitivitas. ${ }^{7}$ Protesa dapat $^{\text {Preng }}$ mengembalikan tampilan alami dan menghilangkan trauma akibat disfungsi dan menunjukkan suatu terapi psikologis yang efisien. ${ }^{4}$

Keberhasilan suatu protesa selalu terbatas pada ketersediaan bahan yang memenuhi persyaratan ideal serta keterampilan dari seorang prosthodontist. Bahan yang saat ini paling disukai sebagai pilihan untuk rehabilitasi prostetik pasca amputasi adalah elastomer silikon. Bahan ini merupakan pilihan karena warna dapat disesuaikan dengan warna kulit sehingga penampilan tampak alami.$^{1,5,7}$

Sebagian besar bahan elastomer silikon yang digunakan untuk protesa adalah silikon room temperature vulcanizing (RTV) yaitu sedian silikon yang dapat mengeras pada suhu kamar. ${ }^{5}$ Keuntungan dari silikon RTV yaitu tidak menimbulkan reaksi kimia, fleksibel, dan elastis. Selain itu bahan ini mudah dibentuk dan diwarnai. ${ }^{5,9}$

\section{METODE}

Seorang pasien laki -laki, 24 tahun datang ke klinik Prostodonsia Rumah Sakit Gigi dan Mulut Prof. Soedomo, Fakultas Kedokteran Gigi, Universitas Gadjah Mada. Pasien mengeluh sebagian jari telunjuk kanan terpotong akibat kecelakaan tergilas mesin bubut kurang lebih 6 tahun yang lalu. Pasien mengatakan kehilangan kepercayaan diri karena kondisinya sehingga sering merasa enggan berinteraksi sosial seperti sebelum kejadian tersebut. Pasien menginginkan pembuatan jari tiruan untuk mengembalikan bentuk jarinya seperti semula.

Pada pemeriksaan klinis jari telunjuk kanan yang mengalami amputasi tidak menunjukkan tanda-tanda keradangan dan infeksi serta daerah disekitarnya tampak normal. Puncak tunggul tampak membesar dan jari tersebut tidak mampu lagi melakukan pergerakan. Tunggul memungkinkan untuk ditumpangi protesa. Setelah melalui suatu diskusi dengan pasien akhirnya disetujui untuk pembuatan protesa jari pasif. Sebelum memulai perawatan, pasien terlebih dahulu diminta untuk menandatangi inform consent.

Tatalaksana kasus dimulai dengan melakukan pencetakan tangan pasien untuk model studi dengan menggunakan bahan cetak hydrocoloid impression material kemudian dituangi dengan dental stone type III seperti tampak pada Gambar 2

Prosedur dilanjutkan dengan pencetakan jari telunjuk kanan (tunggul amputasi) untuk pembuatan model kerja dengan bahan cetak hydrocoloid impression material kemudian dituangi dengan dental stone type III seperti pada Gambar $3 a$ dan $3 b$ 


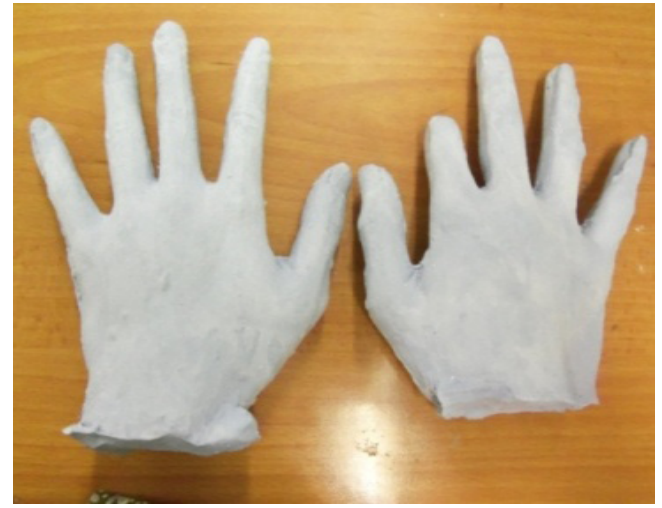

Gambar 2. Hasil cetakan positif model studi tangan pasien

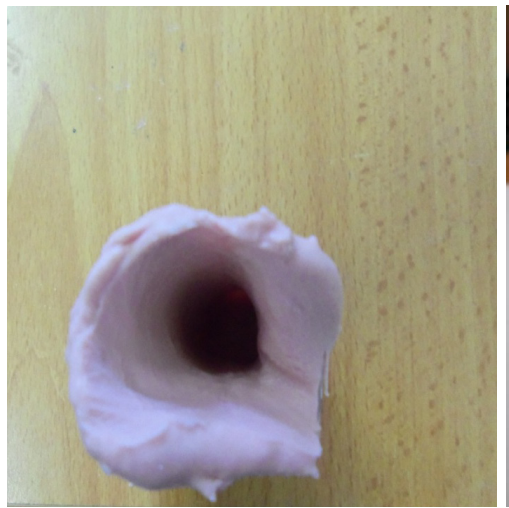

(A)

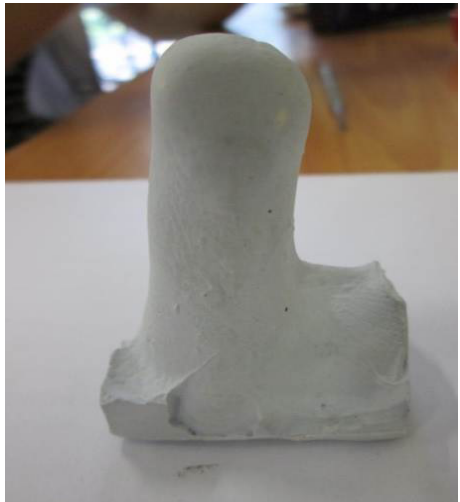

(B)

Gambar 3. Cetakan model kerja tunggul amputasi (A) Cetakan negatif tunggul amputasi, (B) Cetakan positif tunggul amputasi

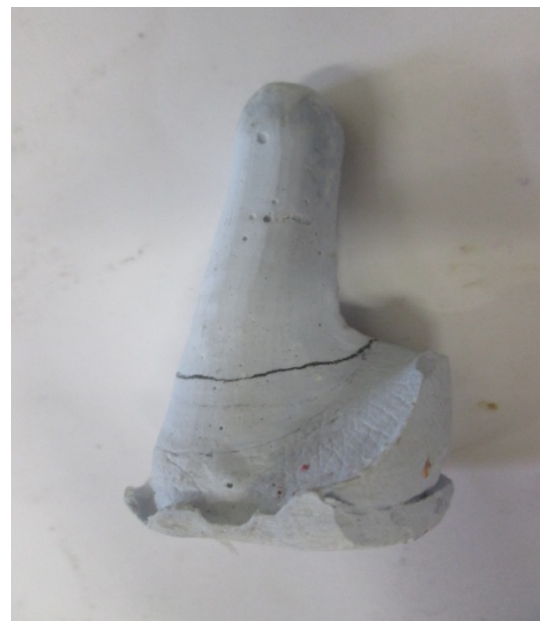

(A)

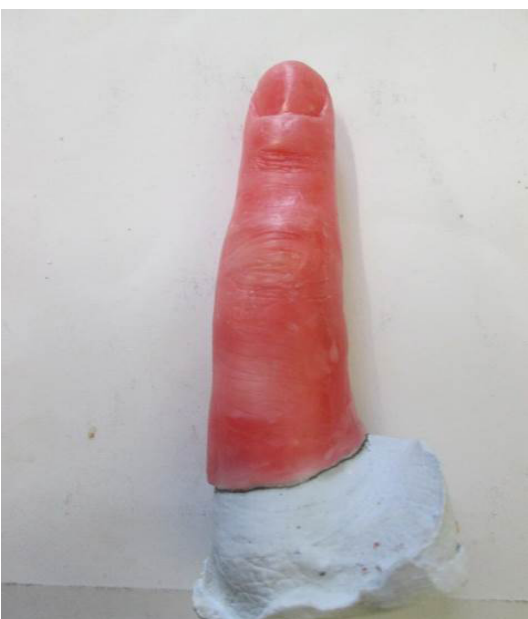

(B)

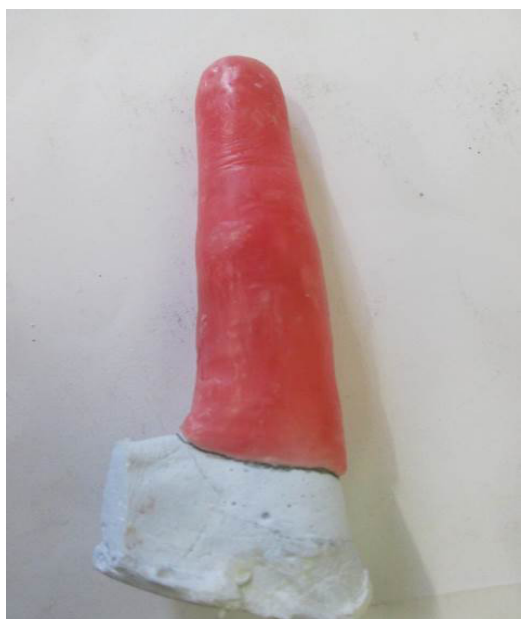

(C)

Gambar 4. Preparasi Model Kerja dan Pembuatan Model Malam (A) Model kerja yang telah diradir bagian marginal line-nya, (B) Model malam yang dibuat diatas model kerja tampak sisi dorsal, (C) Model malam yang dibuat diatas model kerja tampak sisi ventral

Tahapan selanjutnya adalah pemilihan donor yang memiliki ukuran dan bentuk jari yang hampir sama dengan jari pasien, lalu dicetak dengan bahan cetak hydrocoloid impression material. Cetakan dituangi malam merah yang telah dicairkan. Cetakan positif model kerja dipreparasi dengan cara meradir margin line protesa $\pm 1,5$ -2 $\mathrm{mm}$ sehingga menghasilkan diameter protesa yang lebih kecil untuk memperoleh retensi protesa seperti yang ditunjukkan pada Gambar 4a. Selanjutnya pembuatan model malam di atas model kerja dengan bantuan cetakan model jari donor yang telah dicor dengan malam merah lalu dilakukan penyesuaian sehingga menyerupai jari pasien seperti terlihat pada Gambar 4b dan 4c.

Untuk menghindari kerusakan pada model malam maka dilakukan try-in model malam dilakukan untuk menghindari kerusakan pada model malam. Try-in dilakukan dengan bantuan selapis tipis selongsong silikon dari bahan silikon RTV 683 dan katalis untuk mencegah rusaknya model malam seperti pada Gambar 5a, kemudian dilakukan penyesuaian dengan jari telunjuk kontralateral sesuai Gambar 5b. 


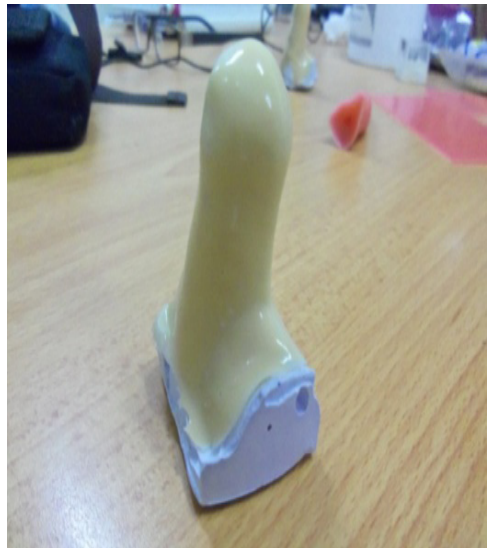

(A)

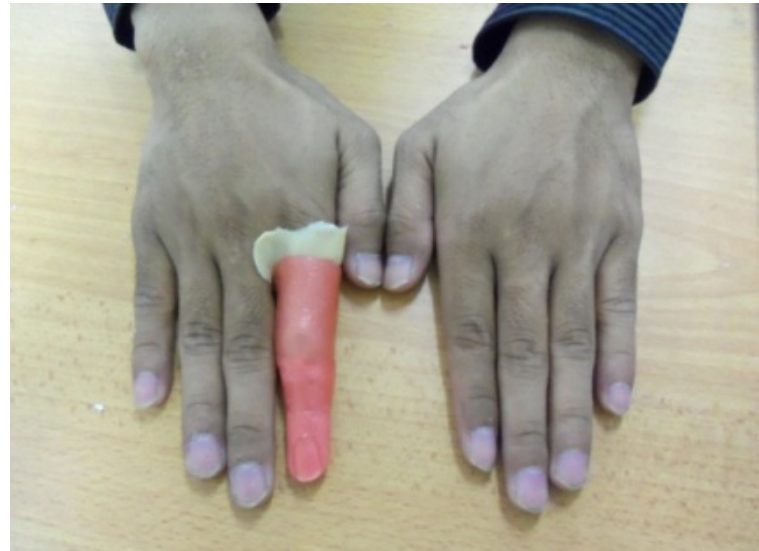

(B)

Gambar 5. Try-in Model Malam Protesa Jari, a. Selongsong dari silikon sebagai alat bantu untuk melakukan try-in model malam, b. Try-in model malanm protesa jari dan penyesuaian dengan bentuk jari kontralateral

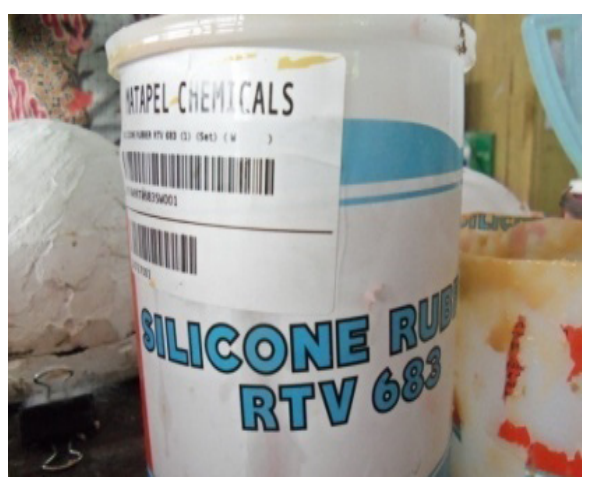

(A)

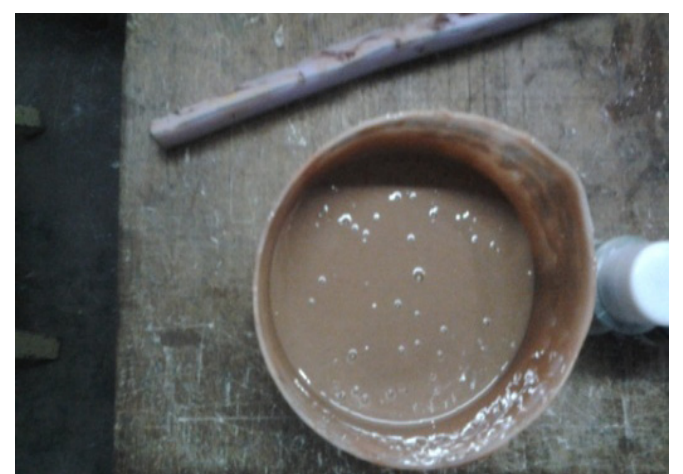

(B)

Gambar 6. Silikon RTV 683 (A) Kemasan silikon RTV 683, (B) Silikon RTV yang telah diberi pewarnaan

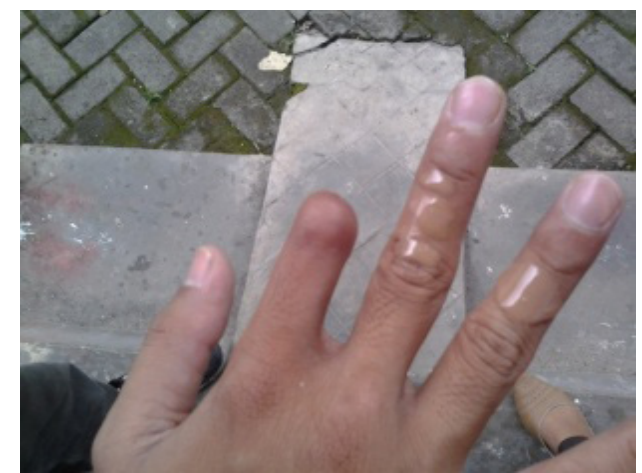

(A)

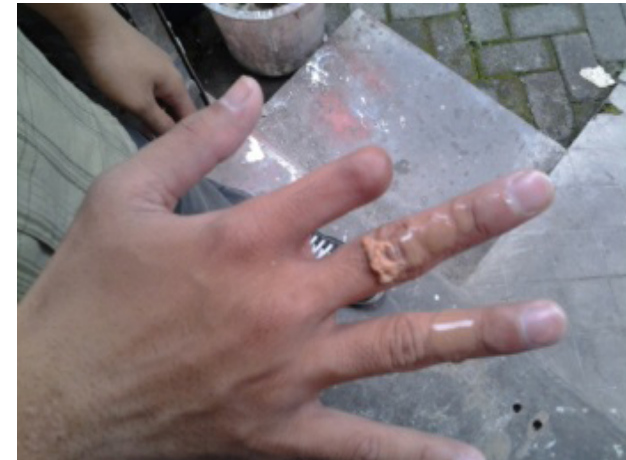

(B)

Gambar 7. Pencocokan warna protesa dengan pencahayaan langsung dilakukan pada siang hari

Tahapan berikutnya adalah pencampuran warna dengan memperhatikan dimensi warna yaitu hue, chroma, value. Silikon RTV 683 dicampur dengan pewarna hingga diperoleh warna sesuai dengan warna kulit pasien seperti tampak pada Gambar 6b
Selanjutnya dilakukan pencocokan warna protesa jari, dengan menghadirkan pasien lalu warna protesa dicocokkan dengan warna kulit pasien dengan pencahayaan langsung pada siang hari seperti terlihat pada Gambar 7a dan 7b 


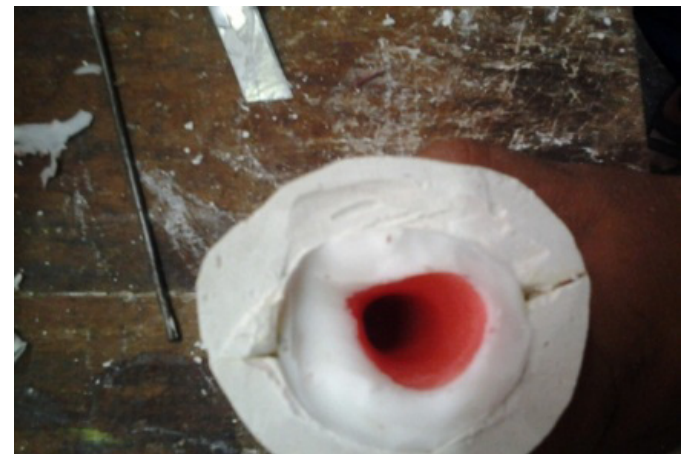

(A)

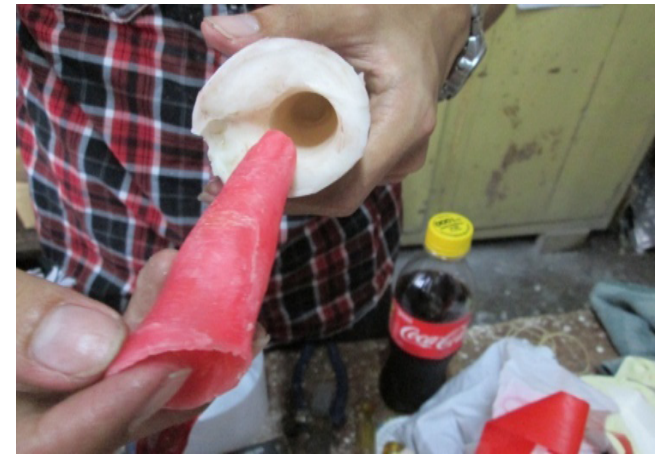

(B)

Gambar 8. Penanaman model malam protesa jari (A). Model malam yang tertanam dalam silikon RTV, (B). Model malam dikeluarkan dari cetakan silikon.

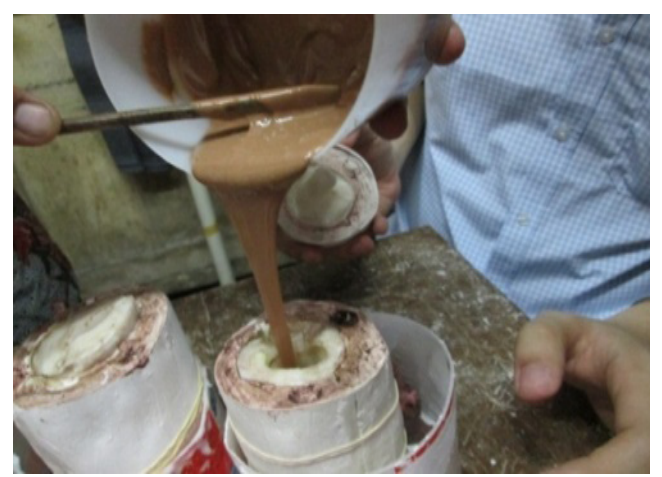

(A)

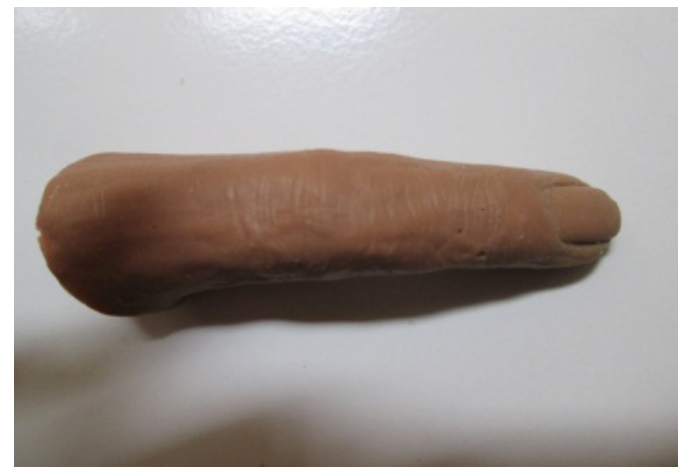

(B)

Gambar 9. Processing protesa jari silikon RTV (A). processing silikon RTV, (B) bentuk positif protesa jari dari bahan silkon RTV

Tahapan berikutnya adalah model malam di boxing dengan lapisan silikon dan bagian luarnya dilapisi plaster of paris lalu ditanam dengan menuangkan cairan silikon ditunggu hingga silikon mengeras kemudian model malam dikeluarkan dari dari cetakan silikon $8 \mathrm{a}$ dan $8 \mathrm{~b}$

Setelah model malam dikeluarkan dari cetakan silikon maka dilakukan processing dengan cara cetakan silikon tadi dituangi adonan silikon berwarna yang telah ditambahkan katalis seperti tampak pada Gambar 9a. Proses pengerasan silkon terjadi selama 24 jam dalam suhu kamar. Setelah 24 jam cetakan dibuka dan protesa jari dari bahan silikon RTV dikeluarkan dari cetakan untuk dilakukan finishing seperti tampak pada Gambar 9b.

Protesa jari diperiksa semua bagiannya tidak ada bagian yang porus serta kelebihan bahan silikon digunting. Kuku dibuat dari resin akrilik curing dingin lalu direkatkan pada protesa dengan perekat cyanoacrylate seperti tampak pada gambar 10a dan 10b.

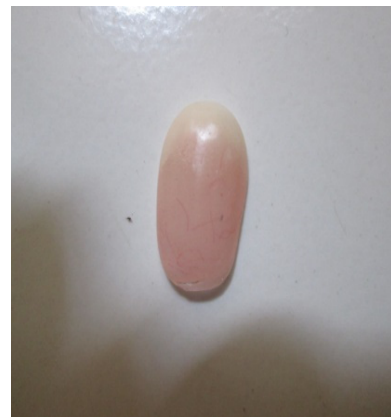

(A)

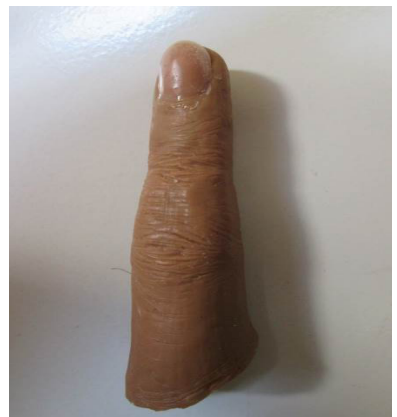

(B)
Gambar 10. Finishing Protesa Jari (A).kuku yang dibuat dengan bahan self curing resin akrilik, (B). Protesa jari yang telah ditambahkan kuku 


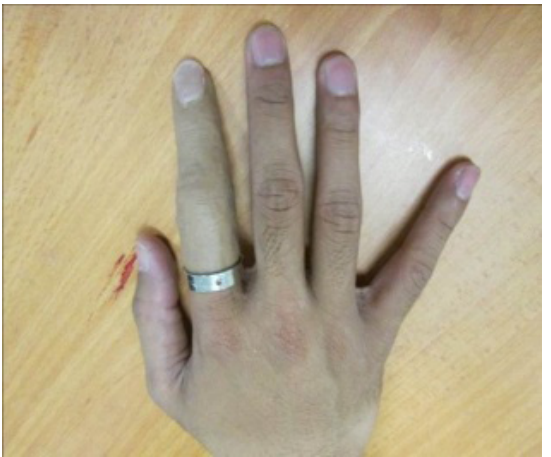

(A)

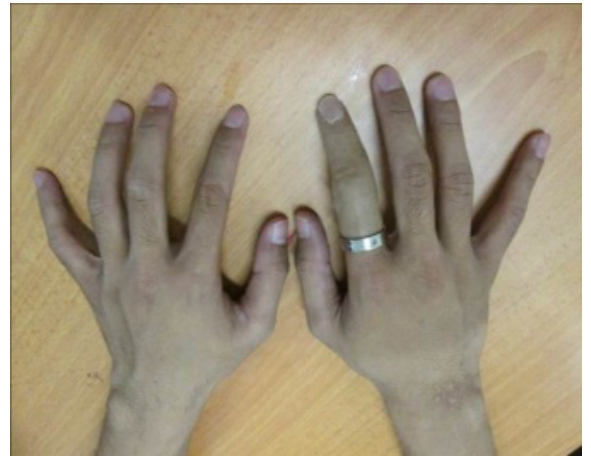

(B)

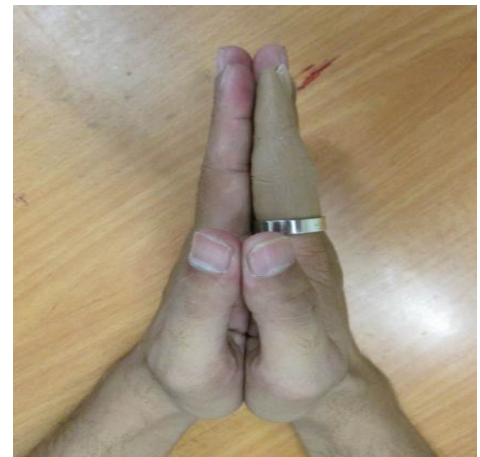

(C)

Gambar 11. Insersi protesa jari silikon, (A). Insersi protesa jari dan pemakaian cincin, (B)\&(C) Penyesuaian dengan jari kontralateral

Setelah finishing selesai tahap selanjutnya dilakukan insersi protesa jari pada tunggul amputasi. Untuk menyamarkan batas protesa maka diperlukan penambahan pemakaian cincin seperti pada Gambar 11a,11b,dan 11c. Bentuk dan kesesuaian panjang serta estetiknya diperiksa dengan jari telunjuk kontralateral.

Kontrol dilakukan 1 minggu setelah insersi. Pada pemeriksaan subyektif tidak terdapat keluhan pasien dan pasien sudah mulai nyaman memakai protesanya. Pemeriksaan objektif tidak tampak adanya perubahan warna (tanda- tanda keradangan) seperti terlihat pada Gambar 12 . Pasien diinstruksikan untuk menjaga kebersihan protesanya

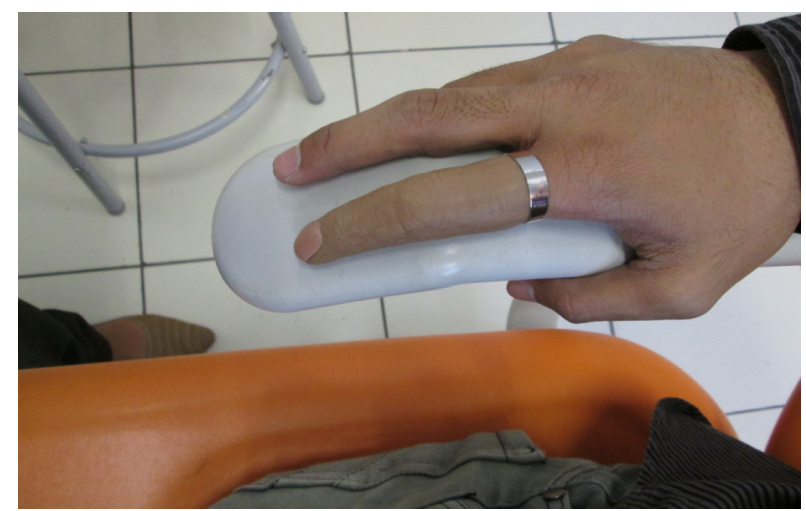

Gambar 19. Protesa jari saat kontrol

\section{PEMBAHASAN}

Amputasi jari dapat menimbulkan berkurangnya fungsi tangan secara signifikan. Selain kehilangan kekuatan untuk menggenggam dan rasa aman, hilangnya jari juga menyebabkan trauma psikologis. ${ }^{5}$

Ketika bedah rekonstruksi bagi pasien amputasi jari merupakan kontra indikasi, gagal, atau tidak dapat dilakukan karena secara finansial pasien tidak mampu maka protesa jari menjadi pilihan perawatan yang dapat memberi dukungan psikologis bagi pasien. Protesa jari yang dibuat dengan tehnik dan estetik yang baik dapat mengembalikan bentuk jari seperti kondisi normalnya serta berfungsi untuk melindungi tunggul amputasi dari rasa nyeri dan sensitivitas. ${ }^{3,4,10}$

Kesuksesan suatu rehabilitasi prostetik merupakan tugas yang menantang bagi seorang prosthodontist. Pemakaian teknik dan bahan terbaik untuk menghasilkan protesa yang menyerupai jaringan asli menimbulkan kesan yang melekat bahwa protesa dapat memberi dukungan psikologis sehingga pasien dapat bersosialisasi dengan penuh percaya diri. ${ }^{5}$

Karakteristik penting dari protesa harus berkualitas tinggi baik secara teknis maupun estetik diantaranya menyerupai jari tangan kontra lateral, warna harus sesuai dengan warna kulit alami, tidak boleh dipengaruhi oleh variasi iklim, tahan panas, noda tidak mudah menempel, tidak mengiritasi, dan dapat dibersihkan dengan mudah. ${ }^{3}$

Silikon yang sering digunakan untuk bahan protesa maksilofasial prostodontik adalah silikon RTV. Kelebihan silikon RTV antara lain : proses polomerisasi pada suhu ruang, tidak mudah robek dan rusak, kemampuan elongasi material yang 
baik, pengerutan minimal saat polimerisasi, tekstur permukaan dan kekerasan berada pada rentang kulit manusia, membutuhkan sedikit instrumen dalam pembuatan, kekuatan tensil optimal, serta proses pewarnaan yang mudah. ${ }^{8}$

\section{KESIMPULAN}

Rehabilitasi prostetik protesa jari menggunakan bahan silikon RTV merupakan salah satu perawatan dengan pertimbangan untuk mengembalikan bentuk dan estetik guna menghilangkan trauma psikologis .

\section{DAFTAR PUSTAKA}

1. Alva H, Prasad K, Shetty M. Prosthetic Rehabilitation of extra-oral defects with silicone prostthesis. J Health Science. Desember 2012; 2 (4): 12-15

2. Shanmuganathan $\mathrm{N}$, Maheswari MU, Anandkumar V, Padmanabhan T V, Swarup $\mathrm{S}$, Jibran $\mathrm{AH}$. Aesthetic finger prosthesis. J Indian Prosthodont Soc H. Juni 2011; 11 (4) : 232-237
3. Kamble VB, Desai RG, Arabbi KC, Mahajan K, Patil S. Finger prostheses for multiple finger amputations : two case report. NJMDR 2013; 1(2): 38-42

4. Goiato MC, Mancuso DN, Ferreira PP, Santos DM. Finger prosthesis: The art of reconstruction. J Coll Physicians Surg Pak. 2009; 19 (10) : 670-671

5. Arora D, Singh $S$, Shakila R, Jagdish SK, Anand S, Kumar VR, Balaji J. Finger Prostheses - Overcoming a Social Stigma. Clinical Case Reports I J M D. 2011; 2 (1): 407-410

6. Cabibihan JJ. Patient-specific prosthetic finger by remote collaboration - Case Study Plo $S$ One 2011;6(5): e 19508

7. Pillet J. Esthetic Hand Prostheses. J Hand Surg Am. 1983; 8 : 78-781

8. Bulbulian AH Facial Prosthetics Charles C Thomas Publisher, Springfields, Illinois, 1973; 105-113

9. Pilley MJ, Quinton DN. Digital prostheses for single finger amputations. JHand Surg $\mathrm{Br}$. 1999; 24(5) : 539-541

10. Livingstone D P. The D-z stump protector.Am J Occup Ther. 1988; 42 :85-187 